\title{
Tissue culture techniques in the proliferation of shoots and roots of Calendula officinalis ${ }^{1}$
}

\author{
Utilização de técnicas de cultura de tecidos na proliferação de brotos e enraizamento \\ de Calendula officinalis
}

\author{
Cristiane Pimentel Victório ${ }^{2 *}$, Celso Luiz Salgueiro Lage ${ }^{3}$ e Alice Sato ${ }^{4}$
}

\begin{abstract}
The high demand for plant material from Calendula officinalis in the production of herbal medicines and cosmetics, turns the technique of plant-tissue culture into one of the alternatives for the improvement of crops over a short period of time. A protocol for tissue culture was developed from segments of seedlings of $C$. officinalis, in order to improve the proliferation of shoots and roots. We used a Murashige and Skoog $\left(\mathrm{MS}^{1} 12 \mathrm{~N}\right)$ medium, reduced to half the concentrations of NH4NO3 and KNO3 to verify the effect of different types of explants (basal, intermediate, and apical), a medium containing beach sand as support instead of agar, and the effect of auxins and cytokinins (TDZ tidiazuron; BAP, 6-benzylaminopurine, IAA, indol-3-acetic acid, IBA, indol-3-butyric acid, NAA, naphthalene-acetic acid) on plant development in vitro. The results showed pronounced rooting from the apical explants, as well as a greater elongation of shoots and number of leaves. The solid medium was more suitable for the C. officinalis cultures. Shoot proliferation was dependent on cytokinins with better results from the influence of TDZ or BAP compared to the other treatments. Plants regenerated from the medium containing TDZ displayed a glazed appearance and morphogenetic deformations. The highest rate for rooting $(80 \%)$ was obtained using IAA $0.1 \mathrm{mgL}^{-1}$. Through in-vitro propagation, healthy $C$. officinalis plants were obtained with roots which can acclimatise, allowing the continuous supplement of raw material.
\end{abstract}

Key words: Medicinal plant. Shoots (Plants). Plant-tissue culture. Plant-growth regulators.

RESUMO - A alta demanda por material vegetal de Calendula officinalis para produção de fitoterápicos e cosméticos, configura a técnica de cultura de tecidos vegetais como uma das alternativas para o aprimoramento das culturas em curto período de tempo. Um protocolo de cultura de tecidos foi desenvolvido a partir de segmentos de plântulas de C. officinalis, no intuito de melhorar a proliferação de brotos e o enraizamento. Foi utilizado o meio Murashige e Skoog (MS1/2N) reduzido à metade das concentrações de $\mathrm{NH}_{4} \mathrm{NO}_{3}$ e $\mathrm{KNO}_{3}$, para verificar o efeito de diferentes tipos de explantes (basal, intermediário e apical), meio contendo areia de praia como suporte em substituição do agar, e o efeito de citocininas e auxinas (TDZ, tidiazuron; BAP, 6-benzilaminopurina; AIA, ácido indol-3-acético; AIB, ácido indol-3-butírico; ANA, ácido naftaleno acético) no desenvolvimento vegetal in vitro. Os resultados mostraram pronunciado enraizamento a partir dos explantes apicais, e também maior alongamento dos brotos e número de folhas. O meio sólido foi mais apropriado para as culturas de C. officinalis. A proliferação de brotos mostrou-se dependente de citocininas, com melhores resultados sob efeito de TDZ ou BAP em relação aos outros tratamentos. As plantas regeneradas a partir do meio contendo TDZ apresentaram aspecto vitrificado e deformações na morfogênese. A maior taxa de enraizamento (80\%) foi obtida utilizando AIA $0.1 \mathrm{mg} \mathrm{L}^{-1}$. Através da propagação in vitro foram obtidas plantas de $C$. officinalis saudáveis e com raízes, capazes de serem aclimatizadas, e permitindo contínuo suplemento de matéria-prima.

Palavras-chave: Plantas medicinais. Brotos (Plantas). Cultura de tecidos vegetais. Reguladores de crescimento vegetal.

\footnotetext{
*Autor para correspondência

${ }^{1}$ Recebido para publicação em 31/01/2011; aprovado em 08/02/2012

Pesquisa financiada pela CAPES/FINEP e Laboratório Simões Ltda

${ }^{2}$ Centro Universitário Estadual da Zona Oeste/UEZO, Campo Grande-RJ, Brasil, 23.070-200, cristianevictorio@uezo.rj.gov.br

${ }^{3}$ Instituto Nacional da Propriedade Industrial/INPI, Rio de Janeiro-RJ, Brasil, 20.081-240, clslage@inpi.gov.br

${ }^{4}$ Universidade Federal do Estado do Rio de Janeiro/UNIRIO, Urca, Rio de Janeiro-RJ, Brasil, alicesato@unirio.br
} 


\section{INTRODUCTION}

Calendula officinalis L. (Asteraceae) plant material is an important source of raw material for the production of phytomedicines, as well as cosmetics and foods. Most phytotherapeutics use raw material from this species to produce ointments, tinctures, and fluid extract. However, a great quantity of $C$. officinalis raw material is imported, resulting in high costs. In addition, Brazilian industries that use this raw material cannot meet market demand or even store sufficient supplies because of unreliable producers, adulteration of product, and lack of quality control. Thus, there is increasing interest in new methods of easily obtaining this raw material for regular production of phytomedicines. Moreover, in Brazil, a gradual process has been implemented to regulate phytotherapeutic products, placing additional pressure on producers to apply novel biotechnologies to improve the quality of plant material.

Tissue culture techniques have been widely used for the fast production of uniform, pathogen-free, and high-quality plants on a commercial scale. Therefore, in vitro propagation of $C$. officinalis would be an important step in supplying the demand for such plants. Development of $C$. officinalis on hormone-free medium was previously shown to produce low rates of root formation and plant production (VICTÓRIO et al., 2008). Indeed, complete plant development through tissue culture strongly relies on interactions between cytokinins and auxins, as these plant hormones influence many aspects of plant cell growth and differentiation (GARCÍA-GONZÁLES et al., 2010; KYOZUKA, 2007). It is always challenging to adjust the appropriate hormonal balance to successfully develop a particular species on culture media. The application of biotechnology has led to increased standardization and high quality of medicinal plants through the use of tissue cultures to supply the phytoherapeutics industry. Therefore, this work evaluated different explant sources and media for in vitro plant development of $C$. officinalis, as well as the effects of adding cytokinins and/or auxins, with the goal of testing different treatments to enhance shooting and rooting and thus improve the production $C$. officinalis plantlets through micropropagation.

\section{MATERIAL AND METHODS}

Tissue cultures were initiated from Calendula officinalis L. seeds. The seed tegument was completely removed, and surface sterilization was performed according to Victório and Lage (2009a). After in vitro seed germination, nodal segments $(1.0-1.2 \mathrm{~cm})$ were excised from plantlets and inoculated in medium MS (MURASHIGE; SKOOG, 1962) to produce new plants that were subcultured during a series of 45-day periods over the course of 1 year to obtain the biomass required to initiate treatments. Individual clones were then selected and monoclonal cultures used to apply the treatments described below. Nodal segments excised from 45-day-old clonal plantlets were placed in six vessels (141 x $72 \mathrm{~mm})$ with 5 explants per vessel, on $50 \mathrm{~mL}$ of modified MS, reduced to half of $\mathrm{NH}_{4} \mathrm{NO}_{3}$ and $\mathrm{KNO}_{3}$ solution $(\mathrm{MS} 1 / 2 \mathrm{~N}$, supplemented with $20 \mathrm{~g} \mathrm{~L}^{-1}$ sucrose, $1.3 \mu \mathrm{M}$ of thiamine$\mathrm{HCl}, 3 \mu \mathrm{M}$ of pyridoxine, $4.1 \mu \mathrm{M}$ of nicotinic acid, $0.6 \mathrm{mM}$ of myo-inositol, $\mathrm{pH}$ rated to $5.8 \pm 0.1$ ) and sterilized in autoclave at $120{ }^{\circ} \mathrm{C}$ and $1.1 \mathrm{kgf} \mathrm{cm}^{-2}$. To solidify media, 7.8 $\mathrm{g} \mathrm{L}^{-1}$ of agar was used. Cultures were maintained for 45 days at $25 \pm 2{ }^{\circ} \mathrm{C}$ under white light (Sylvania F20 W T12) at an intensity of 30 moles $\mathrm{m}^{-2} \mathrm{~s}^{-1}$ and a photoperiod of $16 \mathrm{~h}$. For all treatments, morphogenesis was evaluated at 15, 30 and 45 days, considering these criteria: shoot number, shoot height, leaf number and rooting.

\section{Effect of different explant source on plant development}

Nodal segments from apical, intermediate and basal region were excised from 45-day-old clonal plantlets and placed in vessels on $50 \mathrm{~mL}$ of $\mathrm{MS}^{1} / 2 \mathrm{~N}$. The experimental design was randomized with two replicates of 30 nodal segment types. Data were statistically analyzed by ANOVA followed by the Tukey`s test $(p \leq 0.05)$.

\section{Effect of solid medium and liquid medium, plus sand as support, on growth}

Nodal segments, independent of position, were placed in vessels containing $40 \mathrm{~mL}$ of liquid $\mathrm{MS}^{1} 12 \mathrm{~N}$ plus $60 \mathrm{~g}$ of beach sand ( 0.25 to $0.125 \mathrm{~mm}$ grain size) used as support. The sand was rinsed in running water, immersed in $0.2 \%$ $\mathrm{H}_{2} \mathrm{SO}_{4}$ for $24 \mathrm{~h}$, followed by several rinses in sterile water to remove $\mathrm{H}_{2} \mathrm{SO}_{4}$ traces and further sterilized by autoclaving $\left(120^{\circ} \mathrm{C}, 1.1 \mathrm{Kgf} \mathrm{cm}^{-2}, 15 \mathrm{~min}\right)$. The following treatments were evaluated: solid $\mathrm{MS}^{1} / 2 \mathrm{~N}$ (control 1) with the same composition above, liquid $\mathrm{MS}^{1 / 2} \mathrm{~N}$ plus beach sand (control 2), and liquid $\mathrm{MS} 1 / 2 \mathrm{~N}$ with the addition

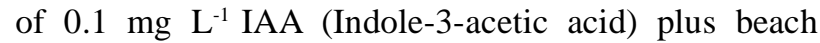
sand. The adopted experimental design was completely randomized with two replicates and 30 explants per treatment $(n=60)$. Data were statistically analyzed by ANOVA followed by the Tukey`s test $(p \leq 0.05)$.

\section{Effect of cytokinins (TDZ, BAP) on plant development}

The effects of TDZ (Thidiazuron) and BAP (6Benzylaminopurine) in improving the production of $C$. officinalis plantlets were evaluated using the following concentrations: 0.0 (control), $0.2 ; 0.5 ; 0.8 \mathrm{mg} \mathrm{L}^{-1}$. Their effects were also evaluated in combination with the auxin IAA: IAA $\left(0.1 \mathrm{mg} \mathrm{L}^{-1}\right)+\mathrm{TDZ}\left(0.1\right.$ or $\left.0.5 \mathrm{mg} \mathrm{L}^{-1}\right)$ and IAA $\left(0.1 \mathrm{mg} \mathrm{L}^{-1}\right)+$ BAP $\left(0.1\right.$ or $\left.1.0 \mathrm{mg} \mathrm{L}^{-1}\right)$. The adopted 
experimental design was completely randomized with three replicates and 30 explants per treatment $(n=90)$. Treatment effects were analyzed by ANOVA at 5\% significance level using Tukey`s test. If any TDZ concentration failed to elongate the shoot, then 45-day-old plantlets from TDZ media were transferred to a medium without growth regulators $\left(\mathrm{MS}^{1} / 2 \mathrm{~N}\right)$ to elongate, and the shoot height was measured after 45 days.

\section{In vitro Rooting}

Nodal segments, independent of position, were placed in vessels containing $60 \mathrm{~mL}$ of solid $\mathrm{MS} 1 / 2 \mathrm{~N}$. The following experiments were evaluated to improve rooting: (1) solid $\mathrm{MS} 1 / 2 \mathrm{~N}$ plus additional auxins: IAA, IBA (Indole-3-butyric acid) and NAA (Naphthalene acetic acid). The experiment was arranged as a randomized complete design, with three replicates $(n=60)$ for treatments using IAA, NAA and IBA with concentrations of $0.0,0.25,0.5$ and $1.0 \mathrm{mg} \mathrm{L}^{-1}$. Data were statistically analyzed by ANOVA followed by the Tukey`s test $(p \leq 0.05)$. A test of difference between two percentages was conducted, considering $p \leq 0.05$ level, $t$-test.

\section{Acclimatization}

Piraí City (Rio de Janeiro State, Brazil), the place of acclimatization, is located between the geographic coordinates $22^{\circ} 37^{\prime} 45^{\prime \prime} \mathrm{S}$ and $43^{\circ} 53^{\prime} 53^{\prime \prime} \mathrm{W}$, at high altitude, providing cool temperatures. Under the Kooppen climate classification, Piraí City has a humid tropical climate (Cwa). About 30 plantlets of 6 to $8 \mathrm{~cm}$ in length were transferred to seed pots $\left(9 \mathrm{~cm}^{2}\right.$ area $)$ containing a sand and humus mixture (2:1). To maintain humidity, the plants were covered with plastic caps and gradually opened during the two-week acclimatization. Plants were grown in a greenhouse for 15 days, at temperatures ranging from $12.3{ }^{\circ} \mathrm{C}$ to $24.1^{\circ} \mathrm{C}$, and watered once a day. Survival of transplanted plants was monitored.

\section{RESULTS AND DISCUSSION}

The use of different plant regions as distinct explant sources is an option to decrease costs and obtain plants without plant growth regulator residues. Regenerative frequency was $100 \%$ from all explant sources. The number of leaves per shoot was the highest from the apical region; such a result was maintained throughout the development period of 15, 30, and 45 days. Similar results were found for shoot elongation; however, the same region produced the lowest number of shoots. Within 45 days, dramatic differences were observed among explants. The apical region produced $40 \%$ of rooted plantlets, while the percentage of rooting decreased significantly when basal and intermediate regions were used (Table 1).

Shoots in treatments containing $0.1 \mathrm{mg} \mathrm{L}^{-1}$ IAA in liquid medium developed $39 \%$ of rooting plants, but the same IAA concentration promoted $64 \%$ of rooting plants when in solid medium (Table 2). Plantlets cultured on liquid medium presented senescent leaves within 30 days. Solid medium induced a higher number and greater height of shoot than liquid $M \mathrm{MS}^{1} / 2 \mathrm{~N}$.

Tissue culture of $C$. officinalis was reproducible for six subcultures, with slight changes in shoot height (4.2-5.4 cm). Plantlets cultured in $\mathrm{MS}^{1} 1 / 2 \mathrm{~N}$ produced a maximum of two shoots per explant (Figure 1 and Table 3). Cytokinins improved the production of $C$. officinalis plantlets when compared to control. TDZ was less effective compared to BAP because shoots from any TDZ concentration failed to elongate (Figure 2), confirming studies where TDZ inhibits shoot elongation (LEDBETTER; PREECE, 2004). Plantlets from control medium and medium supplemented with BAP reached a height of $4.5 \mathrm{~cm}$ and $3.3 \mathrm{~cm}$, respectively (Table 3). Forty-five-day-old plantlets developed in TDZ media were transferred to a medium without growth regulators to elongate. Results such as reduced height and vitrification were verified for plantlets cultured with additional TDZ. Four subcultures intercalated by four transfers were required for the TDZ treatments, all within the one-year period. After subculture in $0.8 \mathrm{mg} \mathrm{L}^{-1} \mathrm{TDZ}$, the greatest percentage of shoot elongation in control medium was $59 \%$, reaching a maximum height of $5.1 \mathrm{~cm}$ (Table 2). Plantlets from TDZ media also showed residual effects for two consecutive subcultures in $\mathrm{MS} 1 / 2 \mathrm{~N}$ (control medium),

Table 1 - Morphogenic responses of Calendula officinalis plantlets developed from different explant sources, within 45 days

\begin{tabular}{lccc}
\hline \multicolumn{3}{c}{ Explant source } \\
\hline Rooting \% & Apical & Intermediate & Basal \\
Shoot number & $40.0 \mathrm{a}$ & $2.2 \mathrm{~b}$ & $8.3 \mathrm{~b}$ \\
Shoot height $(\mathrm{cm})$ & $1.4 \pm 0.6 \mathrm{~b}$ & $1.8 \pm 0.7 \mathrm{a}$ & $1.5 \pm 0.6 \mathrm{ab}$ \\
Leaf number & $5.2 \pm 2.0 \mathrm{a}$ & $3.7 \pm 1.4 \mathrm{~b}$ & $3.7 \pm 1.6 \mathrm{~b}$ \\
\hline
\end{tabular}

Each value is the average \pm SE $(n=60)$. Different letters denote statistical differences among treatments within each experiment, $p \leq 0.05$ 
Table 2 - Morphogenic responses of Calendula officinalis plantlets developed using solid or liquid MS1/2N media, within 45 days

\begin{tabular}{lcccc}
\hline \multicolumn{4}{c}{ Solid* $\mathrm{x}$ Liquid** media } \\
\hline & $\mathrm{MS} 1 / 2 \mathrm{~N}^{*}($ control 1) & $\mathrm{MS}^{1} / 2 \mathrm{~N}^{*}+0.1 \mathrm{IAA}$ & $\mathrm{MS}^{1 / 2 \mathrm{~N}^{*} *}+$ sand (control 2) & $\mathrm{MS}^{1 / 2 \mathrm{~N}^{* *}+\text { sand 0.1 IAA }}$ \\
\hline Rooting $\%$ & $20.0 \mathrm{c}$ & $64.0 \mathrm{a}$ & $3.0 \mathrm{~d}$ & $39.0 \mathrm{~b}$ \\
Shoot number & $1.9 \pm 0.6 \mathrm{a}$ & $1.5 \pm 0.5 \mathrm{~b}$ & $1.6 \pm 0.7 \mathrm{~b}$ & $1.4 \pm 0.7 \mathrm{~b}$ \\
Shoot height $(\mathrm{cm})$ & $4.4 \pm 1.9 \mathrm{a}$ & $4.9 \pm 2.5 \mathrm{a}$ & $3.2 \pm 1.9 \mathrm{~b}$ & $3.3 \pm 1.2 \mathrm{~b}$ \\
Leaf number & $4.0 \pm 1.8 \mathrm{~b}$ & $7.0 \pm 3.4 \mathrm{a}$ & $3.8 \pm 1.9 \mathrm{~b}$ & $4.7 \pm 1.3 \mathrm{~b}$ \\
\hline
\end{tabular}

Each value is the average $\pm \operatorname{SE}(n=60)$. *Solid MS $1 / 2 \mathrm{~N}$ (addition of agar), **Liquid MS1/2N (beach sand as support). Different letters denote statistical differences among treatments within each experiment, $p \leq 0.05$. IAA: indole-3-acetic acid

which included the absence of roots in addition to reduced shoot height and leaf size. Each plantlet obtained from medium supplemented with BAP provided about three explants to initiate new subcultures. This hormone promoted the greatest shoot formation, and the addition of BAP induced a high production of new plants per year.

Rooting was inhibited in medium supplemented with IAA and any cytokinin. In addition, treatments where BAP was present resulted in plants with very low numbers of roots, while the use of TDZ resulted in plants without roots. High production of plantlets suitable for acclimatization was obtained on media supplemented with auxins rather than cytokinins (Table 2 and Table 4).

At 0.1 and $1.0 \mathrm{mg} \mathrm{L}^{-1}$ IAA concentrations, the acceleration of rooting was observed. After 15 days, rooting was $55 \%$ and $73 \%$, respectively, without significant difference between 15 and 45 days. Addition of $0.1 \mathrm{mg} \mathrm{L}^{-1}$ IAA or IBA was enough to improve rooting (Table 4). In response to increasing the IAA concentration to $0.3 \mathrm{mg} \mathrm{L}^{-1}$, rooting was unchanged, although IAA $1.0 \mathrm{mg} \mathrm{L}^{-1}$ was superior in inducing $80 \%$ of rooting. Auxins promoted the development of fragile roots, requiring considerable care in transferring plantlets to soil. At $0.1 \mathrm{mg} \mathrm{L}^{-1}$ IAA, about $30 \%$ of callogenesis was observed, against $26 \%$ of control medium. The produced calli were generally green or white.

Plantlets were acclimatized with a survival frequency of $92.9 \%$ (Figure 3). Rooting increased rapidly within one week, and plants were transferred to soil. After two months, the increase in height in soil was an average of $19.9 \mathrm{~cm}$. The highest growth was verified between the third and fourth weeks. In approximately two and a half months, the plants began to develop adventitious shoots and flowers.

Improvement of shoot elongation and the absence of vitrified plants resulted from reducing the nitrogen content in the MS medium, a phenomenon verified in other cultures and in previous studies of $C$. officinalis and Phyllanthus tenellus using basic MS (VICTÓRIO et al., 2008; VICTÓRIO; LAGE, 2009b; VICTÓRIO et al., 2010). Nitrogen is involved in essential physiological and biochemical processes that regulate plant growth, differentiation and morphogenesis

Figures 1 - Thirty-day-old plantlets of Calendula officinalis: 1) MS1 $1 \frac{2}{2}$; 2) MS1/2N + TDZ (thidiazuron, 0.8 mg L $^{-1}$ ); 3 ) Acclimatized plant at 2 months after transferring to soil. Bar= $1 \mathrm{~cm}$
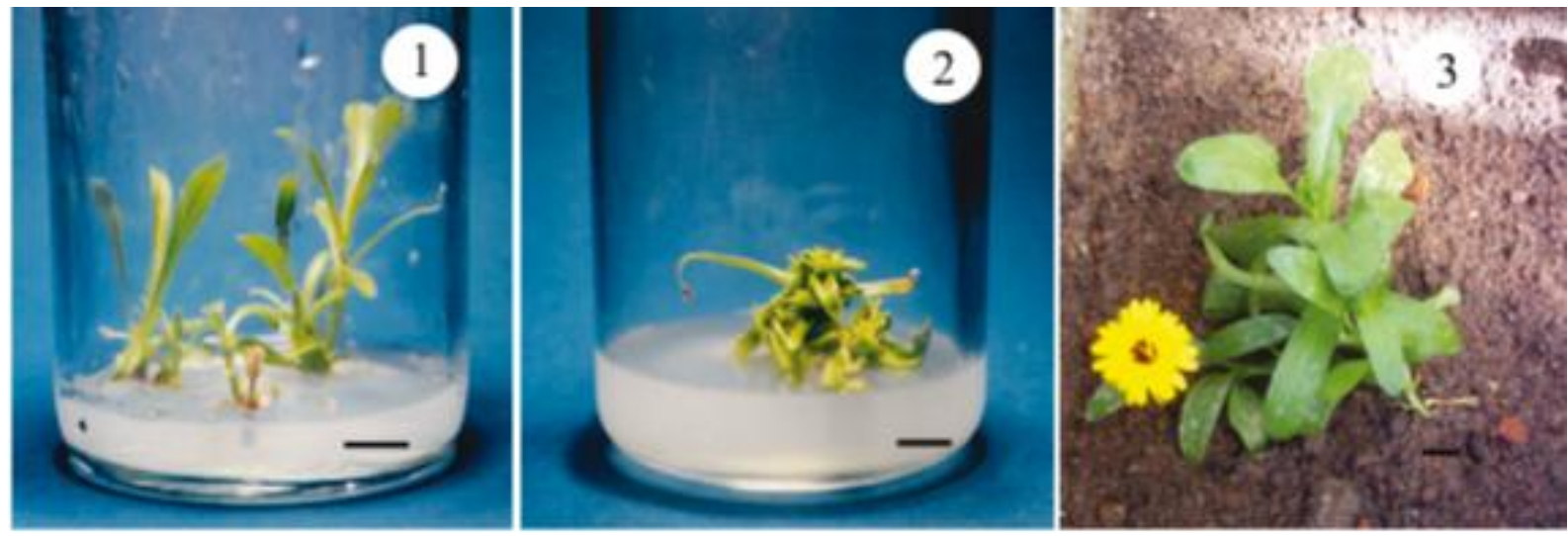
Table 3 - Influence of TDZ and BAP cytokinin concentrations alone or in combination with IAA auxin on in vitro proliferation of Calendula officinalis plantlets, within 45 days

\begin{tabular}{|c|c|c|c|c|c|c|}
\hline \multirow{2}{*}{ Treatments (mg L $\left.{ }^{-1}\right)$} & \multirow{2}{*}{ Shoot number } & \multirow{2}{*}{$\frac{\text { Shoot }}{\text { height }(\mathrm{cm})}$} & \multirow{2}{*}{$\begin{array}{c}\text { Elongated } \\
\text { shoots } *(\mathrm{~cm})\end{array}$} & \multirow{2}{*}{ Leaf number } & \multirow{2}{*}{ Rooting (\%) } & \multirow{2}{*}{ Callogenesis (\%) } \\
\hline & & & & & & \\
\hline Control & $1.7 \pm 0.6 \mathrm{~b}$ & $4.5 \pm 0.3 \mathrm{a}$ & & $5.7 \pm 2.5 \mathrm{ac}$ & 8.3 & $8.1 \mathrm{c}$ \\
\hline TDZ 0.2 & $3.5 \pm 1.0 \mathrm{a}$ & $1.4 \pm 0.4 \mathrm{bc}$ & $5.1 \pm 0.8 \mathrm{a}$ & $4.4 \pm 1.2 \mathrm{~b}$ & 0.0 & $100 \mathrm{a}$ \\
\hline 0.5 & $3.1 \pm 0.9 \mathrm{a}$ & $1.4 \pm 0.5 \mathrm{bc}$ & $1.7 \pm 0.1 b$ & $4.6 \pm 1.4 \mathrm{~b}$ & 0.0 & $100 \mathrm{a}$ \\
\hline 0.8 & $3.4 \pm 1.1 \mathrm{a}$ & $1.2 \pm 0.4 \mathrm{~b}$ & $3.4 \pm 0.5 \mathrm{ab}$ & $4.6 \pm 1.2 b$ & 0.0 & $100 \mathrm{a}$ \\
\hline BAP 0.2 & $2.4 \pm 0.9 \mathrm{~b}$ & $3.3 \pm 1.2 \mathrm{~d}$ & & $7.6 \pm 2.5 \mathrm{a}$ & 0.0 & $75.0 \mathrm{~b}$ \\
\hline 0.5 & $2.9 \pm 1.2 \mathrm{a}$ & $3.0 \pm 1.2 \mathrm{~d}$ & & $8.4 \pm 3.1 \mathrm{a}$ & 0.0 & $79.4 \mathrm{~b}$ \\
\hline 0.8 & $3.1 \pm 1.4 \mathrm{a}$ & $2.1 \pm 0.6 \mathrm{c}$ & & $7.1 \pm 2.9 \mathrm{ac}$ & 2.7 & $97.3 \mathrm{a}$ \\
\hline $\mathrm{IAA}+\mathrm{BAP}(0.1)(1.0)$ & $2.3 \pm 0.2 b$ & $3.6 \pm 0.2 \mathrm{a}$ & & $6.5 \pm 0.4 \mathrm{c}$ & 10.0 & $97.5 \mathrm{a}$ \\
\hline $\mathrm{IAA}+\mathrm{TDZ}(0.1)(0.5)$ & $2.8 \pm 0.1 \mathrm{ab}$ & $1.3 \pm 0.03 \mathrm{~b}$ & & $5.6 \pm 0.3 \mathrm{bc}$ & 0.0 & $100 \mathrm{a}$ \\
\hline
\end{tabular}

Each value is the average $\pm \mathrm{SE}(\mathrm{n}=90)$. Different letters denote statistical differences among treatments, $p \leq 0.05$. *Shoot height of 45 -day-old plantlets from TDZ media after 45 days in MS1/2N for elongating. IAA: indole-3-acetic acid; BAP: 6-benzylaminopurine; TDZ: thidiazuron

Table 4 - Morphogenic responses of Calendula officinalis plantlets to different root-enhancing procedures by addition of auxin, within 45 days

\begin{tabular}{lcccccccc}
\hline & MS1/2N & \multicolumn{3}{c}{ IAA } & \multicolumn{3}{c}{ IBA } & \multicolumn{3}{c}{ NAA } \\
\hline & (control) & 0.1 & 0.3 & 1.0 & 0.1 & 0.3 & 0.1 & 0.3 \\
\hline Rooting \% & $26 \mathrm{~d}$ & $64 \mathrm{~b}$ & $43 \mathrm{c}$ & $80 \mathrm{a}$ & $47 \mathrm{bc}$ & $21 \mathrm{~d}$ & $47 \mathrm{bc}$ & $58 \mathrm{~b}$ \\
Shoot number & $1.8 \pm 0.6$ & $1.5 \pm 0.5$ & $1.4 \pm 0.6$ & $1.6 \pm 0.7$ & $1.8 \pm 0.8$ & $1.5 \pm 0.6$ & $1.7 \pm 0.9$ & $1.5 \pm 0.6$ \\
Shoot height $(\mathrm{cm})$ & $4.5 \pm 1.8 \mathrm{~b}$ & $4.9 \pm 2.5 \mathrm{~b}$ & $5.1 \pm 2.2 \mathrm{~b}$ & $7.1 \pm 3.0 \mathrm{a}$ & $5.5 \pm 2.5 \mathrm{ab}$ & $6.0 \pm 2.6 \mathrm{ab}$ & $5.4 \pm 2.9 \mathrm{~b}$ & $5.9 \pm 2.7 \mathrm{ab}$ \\
Leaf number & $7.2 \pm 3.5$ & $7.4 \pm 3.4$ & $6.2 \pm 2.5$ & $7.3 \pm 3.5$ & $6.7 \pm 3.0$ & $6.6 \pm 2.9$ & $7.6 \pm 3.5$ & $6.5 \pm 3.2$ \\
\hline
\end{tabular}

Each value is the average $\pm \mathrm{SE}(\mathrm{n}=60)$. Different letters denote statistical differences among treatments, $p \leq 0.05$. IAA: indole-3-acetic acid; IBA: indole-3-butyric acid; NAA: naphtaleneacetic acid

(HAYASHI et al., 2002), and its content may influence hyperhydricity in plants (HAZARIKA, 2006). The ideal interval for subcultures of $C$. officinalis was 45 days, after which symptoms of senescence began to appear.

Proliferative features of cytokinins TDZ and BAP play various roles in plant development during the formation and activity of shoot meristems (KYOZUKA, 2007). These cytokinins improve proliferative rates in different species (GLOCKE; COLLINS; SEDGLEY, 2006). TDZ is a synthetic cytokinin, which is very efficient in inducing adventitious shoots. BAP is involved in the improvement of shoot proliferation and elongation (GLOCKE; COLLINS; SEDGLEY, 2006). However, the use of TDZ in tissue cultures of $C$. officinalis resulted in shorter plantlets without roots, glassy appearance, and shoot production did not occur after 45 days. Some effects of this cytokinin on rooting may be related to its stimulus of ethylene production (CARY; LUI; HOWELL, 1995). In this study, data revealed slight differences in shoot proliferation between BAP and TDZ at $0.2 \mathrm{mg} \mathrm{L}^{-1}$. No correlations were verified between the increase of TDZ concentration and number of shoots. For plantlets cultured on media containing BAP, the gradual increase of concentration resulted in a greater number of shoots $\left(R^{2}=0.9932\right)$. The main difference between TDZ and BAP involves the production of elongated shoots. The addition of TDZ to the media also reduced shoot height in studies with tissue cultures of $C$. officinalis from cotyledonary node explants (ÇöÇü et al., 2004). Growth regulator combinations were used as agents capable of evoking better responses for simultaneously improving the number of shoots per explant and rooting. Combinations of cytokinins and auxins have stimulated in vitro proliferation and development in several plant species. Again, however, the current study has shown that the combination of BAP plus IAA and TDZ plus IAA did not significantly affect shoot responses, although rooting was slightly increased by BAP and IAA interaction. At $1.0 \mathrm{mg} \mathrm{L}^{-1}$ of IAA and $0.1 \mathrm{mg} \mathrm{L}^{-1}$ of IBA, the best result 
for shoot height was achieved within 15 and 45 days. Generally, reduced levels of auxins are enough to induce root proliferation in herbaceous plants, and in the present study, an inverse correlation was observed between the concentration of auxin and rooting for both IAA and NAA. The efficacy of low IBA concentration may be explained by the greater stability of IBA compared to IAA, which may justify the higher level of IAA required to achieve similar effects (LUDWIG-MüLLER, 2007). Addition of auxin to the medium was essential in improving the production of $C$. officinalis plantlets with developed roots. Auxin treatments resulted in plantlets with greater shoots than plantlets under cytokinins only, probably from the higher in vitro rooting that contributed to the elongation of plants.

The choice of apical region to initiate in vitro cultures of $C$. officinalis replaces the addition of exogenous auxins and is an alternative to obtaining the highest quantity of rooted plants. The explant source is a way to take advantage of the plant potential to synthesize auxins in plant apices (PEER; MURPHY, 2007). Additionally, these results agree with indications that endogenous auxins are mainly biosynthesized at the young developing leaves, shoot apical meristems, and plant stems (BOUTTÉ; IKEDA; GREBE, 2007).

Sand is a chemically inert material, adequately solid, and perfect for diffusion of soluble compounds. The use of sand as support may be a low-cost agar substitute when the objective is the greatest plant production (PRKNOVÁ, 2007). Furthermore, the use of sand as substrate in $C$. officinalis micropropagation was also intended to reduce vitrification, which may be associated with agar properties that influence water retention capacity and water content of the shoots (PRKNOVÁ, 2007), besides improving plant development. Vitrification or hyperhydricity symptoms are characteristic of morphological and physiological disorders where abnormal morphogenesis, translucent aspect, high water content, and poorly developed cell walls can be observed (HAZARIKA, 2006). However, when agar was replaced by sand, as medium support, decreased efficiency of rooting was observed, as well as the production of $C$. officinalis plantlets with glassy appearance. These results could be explained by the physical characteristics of sand, as observed in gelrite, which may allow an increased absorption of substances responsible for hyperhydricity, such as ammonium ions and water (WILLIAMS; TAJI, 1991). Furthermore, the use of liquid medium can also increase the humidity in vessels, thus altering water availability and, hence, plant development (HAZARIKA, 2006).

\section{CONCLUSION}

The use of an apical explant source resulted in a high number of rooted plants. However, when medium was supplemented with $1.0 \mathrm{mg} \mathrm{L}^{-1} \mathrm{IAA}$, rooting was significantly higher, indicating that this was the most suitable medium for short-term production of rooted plantlets. TDZ suppressed the elongation phase of $C$. officinalis plantlets; however, in low concentrations, it provided maximum shooting. The addition of 0.5 or $0.8 \mathrm{mg} \mathrm{L}^{-1} \mathrm{BAP}$ also increased shoot production without reducing elongation. Rapid micropropagation of $C$. officinalis resulted in healthy plants and permitted a continuous supply of raw material. Rooted plantlets were successfully adapted to field conditions.

\section{ACKNOWLEDGEMENTS}

In memoriam to our dear laboratory technician, $\mathrm{Mr}$. Valter Pereira Rodrigues. This study was part of a project to supply the phytotherapeutics industry, establishing a relationship among the university, pharmaceutical laboratories, and governmental entities. This work was supported by RECOPE-FINEP/FAPERJ, CAPES and Laboratório Simões Ltda., Brazil. The authors are grateful to biologist Ms. Maria Núbia for her help in acclimatizing $C$. officinalis and the Municipality of Piraí, RJ, which provided a greenhouse.

\section{REFERENCES}

BOUTTÉ, Y.; IKEDA, Y.; GREBE, M. Mechanisms of auxindependent cell and tissue polarity. Current Opinion in Plant Biology, v. 10, n. 06, p. 616-623, 2007.

CARY, A. J.; LUI, W.; HOWELL, S. H. Cytokinin action is coupled to ethylene in its effects on the inhibition of root and hypocotyls elongation in Arabidopsis thaliana seedlings. Plant Physiology, v. 107, n. 04, p. 1075-1082, 1995.

ÇÖÇÜ, S. et al. Adventitious shoot regeneration and micropropagation in Calendula officinalis L. Biologia Plantarum, v. 48, n. 03, p. 449-451, 2004.

GARCÍA-GONZÁLES, R. et al. Plant tissue culture: Current status, opportunities and challenges. Ciencia e Investigación Agraria, v. 37, n. 03, p. 5-30, 2010.

GLOCKE, P.; COLliNS, G.; SEDGLEY, M. 6-Benzylamino purine stimulates in vitro shoot organogenesis in Eucalyptus erythronema, E. stricklandii and their interspectific hybrids. Scientia Horticulturae, v. 109, p. 339-344, 2006.

HAYASHI, T. K. et al. Nitrogen treatment of carnation (Dianthus caryophyllus L., Caryophyllaceae) and in vitro callogenesis. Scientia Agricola, v. 59, n. 01, p. 47-52, 2002.

HAZARIKA, B. N. Morpho-physiological disorders in in vitro culture of plants. Scientia Horticulturae, v. 108, n. 2, p. 105-120, 2006. 
KYOZUKA, J. Control of shoot and root meristems function by cytokinin. Current Opinion in Plant Biology, v. 10, n. 05, p. 442-446, 2007.

LEDBETTER, D. I.; PREECE, J. E. Thidiazuron stimulates adventitious shoot production from Hydrangea quercifolia Bartr. leaf explants. Scientia Horticulturae, v. 101, n. 01/02, p. 121-126, 2004.

LUDWIG-MÜLLER, J. Indole-3-butyric acid synthesis in ecotypes and mutants of Arabidopsis thaliana under different growth conditions. Journal of Plant Physiology, v. 164, n. 01, p. 47-59, 2007

MURASHIGE, T.; SKOOG, F. A revised medium for rapid growth and bioassays with tobacco tissue cultures. Physiologia Plantarum, v. 15, n. 03, p. 473-497, 1962.

PEER, W. A.; MURPHY, A. S. Flavonoids and auxin transport modulators or regulators? Trends in Plant Science, v. 12, n. 12, p. 556-563, 2007.

PRKNOVÁ, $H$. The use of silica sand in micropropagation of woods. Journal of Forest Science, v. 53, n. 02, p. 88-92, 2007.
VICTÓRIO, C. P. et al. Sucrose on in vitro cultures of Calendula officinalis L. Plant Cell Culture \& Micropropagation, v. 04, p. 34-41, 2008.

VICTÓRIO, C. P.; LAGE, C. L. S. Germinação e desenvolvimento pós-germinativo in vitro de Calendula officinalis L. sob diferentes qualidades de luz. Revista de Biologia e Farmácia, v. 03, n. 01, p. 81-87, 2009a.

VICTÓRIO, C. P.; LAGE, C. L. S. Light quality effects on in vitro germination and initial development of Phyllanthus tenellus. Revista Ciência Agronômica, v. 40, n. 03, p. 400-405, 2009 b.

VICTÓRIO, C. P. et al. Standardized production of Phyllanthus tenellus Roxb. by plant tissue culture. Revista Ciência Agronômica, v. 41, n. 02, p. 272-278, 2010.

WILLIAMS, R. R.; TAJI, A. M. Effect of temperature, gel concentration and cytokinins on vitrification of Olearia microdisca (J.M. Black) in vitro shoot cultures. Plant Cell, Tissue and Organ Culture, v. 26, n. 01, p. 01-06, 1991. 